\title{
Księga krakowska, czyli o Dąbrowskiej inaczej
}

\author{
Ewa GŁĘBickA
}

ORCID: 0000-0002-2848-8680

(Instytut Badań Literackich PAN, Warszawa)

\section{Recenzja KSIĄżKi: RozCZytyWANie Dąbrowskiej, Red. Dorota Kozicka, MoNiKa ŚWIERKosZ, WYdAWNictwo UNIWERSYTETU JAGIELLOŃSKIEgo, KraKów 2018, ss. 342}

$\mathrm{Na}$ krótko przed i3o. rocznicą urodzin autorki Nocy i dni ukazała się ważna publikacja poświęcona jej twórczości; to ponad trzystustronicowa księga Rozczytywanie Dąbrowskiej pod redakcją Doroty Kozickiej i Moniki Świerkosz. Jest ona pokłosiem ogólnopolskiej konferencji, która odbyła się w 2016 roku na Wydziale Polonistyki Uniwersytetu Jagiellońskiego w Krakowie, i zawiera teksty dziewiętnastu autorów starszego i młodszego pokolenia badaczy. Warto podkreślić aspekt pokoleniowości, ponieważ przekłada się on na różne pola zainteresowań i odmienny sposób odczytania dorobku, a także życia pisarki. Mamy tu bowiem ułożone w porządku problemowym w działach Szukanie gtosu, Ogladanie świata, Twórcze sukcesy, twórcze porażki ujęcia „tradycyjne” (nie w sensie zachowawczości, a bardziej wyboru tematu i narzędzi interpretacji) i te związane $z$ trendami badawczymi ostatnich dekad, to jest na przykład odczytań z perspektywy feministycznej. W tym drugim przypadku zresztą autorki wstępu słusznie zastrzegają, że „Zarówno osobowość pisarska, jak i sama twórczość Dąbrowskiej z trudem mieszczą się w kulturowych granicach wyznaczanych literaturze kobiecej i stanowią wyzwanie dla lektury feministycznej” (s. II). Perspektywa ta ulegnie zmianie, gdy zostanie wydana korespondencja Dąbrowskiej z jej wieloletnią przyjaciółką, Anną Kowalską ${ }^{\mathrm{T}}$.

Dobór tematów konferencji, a następnie publikacji pokazuje, co dla dzisiejszego badacza życia i prac Dąbrowskiej jest obszarem atrakcyjnym lub - jak brzmią postulaty ponownego spojrzenia na znane problemy i weryfikacji utrwalonych

1 W ostatnim czasie udało się uzyskać zgodę spadkobierców na wydanie tej korespondencji w całości, pojawiła się więc możliwość rozpoczęcia prac nad edycją. 
sądów. Pomysłodawczynie konferencji (i zarazem redaktorki książki pokonferencyjnej) postawiły przed badaczami dzieła Dąbrowskiej zadanie, wydawałoby się, proste, o wysokim poziomie ogólności: „poszukiwania zarówno wiedzy, jak i lekturowej przyjemności”, uważając, że: „Rozczytywanie wiedzie nas [...] tak do rozkoszowania się lekturą, jak do odkrywania na nowo tekstowych znaczeń”. „Rozczytywanie” jest tu zatem rozumiane jako typ lektury, który nie skupia się na tym, „,o w tekście zostało symptomatycznie ominięte lub stłumione, lecz uważnie wsłuchuje się w to, co w tekście zostało wypowiedziane” (s. I2). Jest wyraziście postawioną perspektywą interpretacyjną, postulującą ponowny powrót do dzieł autorki Nocy $i$ dni w poszukiwaniu tego, co daje się odczytać z takiej, a nie innej realizacji deklarowanych lub zrekonstruowanych intencji twórczych pisarki - „idąc tropem Dąbrowskiej albo wbrew jej samoocenom” (s. I3). Główną refleksją tomu, przewijającą się w wielu studiach, jest uznanie faktu, że sprawy osobiste, polityczne i literackie w życiu i twórczości pisarki łączą się w całość, której nie sposób zbyt ostro rozdzielać i raczej nie należałoby tego robić. Zostało to wyraziście dookreślone w konstatacji o niechronologicznym czytaniu dzieła Dąbrowskiej, która to lektura „rozszczelnia granice oddzielające literackie od biograficznego, literaturę od życia” (s. I3). Taka perspektywa wydaje się właściwą podstawą do rozważań nad formułą badań biograficznych. W tym ujęciu kryje się też nienazwana intencja odpowiedzi na pytanie o znaczenie osoby pisarki i jej dzieła w lekturowych i pozatekstowych oczekiwaniach współczesnego czytelnika, niekoniecznie literaturoznawcy. Dla obu tych kategorii odbiorcy ważne są - jak podkreślają autorki wstępu - „możliwości, jak i ograniczenia projektu pisarskiego Marii Dąbrowskiej; jej pełny rys i pęknięć - arcyciekawy wizerunek" (s. I4). Wydaje się, że obecnie właśnie owe rysy, pęknięcia i niedomówienia szczególnie interesują autorów omawianego tomu i czytelników. Zajmują ich także próby odpowiedzi na pytania: jak owe skazy biografii Dąbrowskiej rzutują na sens i odbiór jej dzieła, jakie są formy jej obecności w grupie pisarzy zaliczanych do klasyków i jak wpływają na dookreślenie miejsca jej twórczości w kanonie literackim oraz w rozmaitych polach badawczych.

Spis treści tomu przekonuje, że w ostatnich latach stopniowo ulega zmianie perspektywa lektury Dąbrowskiej. Wprawdzie Noce i dnie nadal wzbudzają zainteresowanie badaczy, o czym świadczą cztery studia poświęcone powieści, ale nie jest to już lektura całościowa tetralogii, a jedynie skupienie się na wybranych wątkach czy motywach (wątek Agnieszki, motyw śmierci, problematyka pożegnania odchodzącego świata, odautorskie relacje o powieści w Dziennikach). W Rozczytywaniu Dąbrowskiej znalazły się za to teksty, nakierowane na mniej badawczo rozpoznane dokonania autorki. Należy do nich studium Andrzeja 
Mencwela Arcydzieto zapoznane, poświęcone zbiorowi Ludzie stamtad, niewystarczająco docenionemu przez pierwszych, ale i późniejszych jego krytyków, a potem niesłusznie zepchniętemu w cień przez sukces czytelniczy Nocy $i$ dni. Mimo że opublikowany w grudniu I925 roku cykl wspomnieniowych opowieści miał potem kilkanaście wydań, a pojedyncze utwory były przedrukowywane w wyborach opowiadań, tom ten nie doczekał się zbyt wielu poważnych analiz. Studium Mencwela lukę tę w dużej mierze wypełnia. Pierwszy rozpoznał kongenialność tych opowieści Stanisław Stempowski, gdy w liście do Dąbrowskiej z sierpnia I925 roku pisał:

\section{》Jakżeby radował się Abramowski, czytając Tryumf Dionizego [...]. A ja myślę, że wszyscy, co wyszli z niczym w pole przeciw swemu nieszczęściu, zazdrościć będą Dionizemu garba, a Nikodemowi tego, że nie ma nosa, jako że znalazła Pani dla nich cudowne słowo godzące z życiem (list z I9 sierpnia I925 roku) ${ }^{2}$.}

Ciekawe wydaje się świadectwo samej Dąbrowskiej, pokazujące, jak silne więzy łączyły ją ze światem, z którego wyszła, i jak bardzo świat ten zorganizował w późniejszych latach genre jej pisarstwa.
Ludzie stamtad [...] są wysnute i skomponowane z autentycznych wspo- mnień dzieciństwa i dziewczęctwa. Dzieci z małych folwarków bawiły się z dziećmi z czworaków i żyły wśród ludzi folwarcznych. Zachowałam nawet ich prawdziwe nazwiska, przekazałam ich typy psychiczne i przygody, znałam na wylot ich gwarę itp. ${ }^{3}$

Warto przypomnieć, że Ludzie stamtad korespondują z obszernymi partiami Nocy i dni, oddającymi świat równoległy do tego z opowiadań. Dąbrowska dostarczała wielu znaczących wskazówek dotyczących świata przedstawionego w jej utworach. O córce polowego z Russowa, Julce Kaczmarkównie - pojawiającej się w Najdalszej drodze, Zdobyciu serc i Nocach $i$ dniach - pisała do Paula Breitenkampa jako o postaci autentycznej:

Służyła u moich rodziców długie lata i do dziś podtrzymuje ze mną przyjacielskie stosunki. Jest obecnie służącą w domu naszego posła

2 List do M. Dąbrowskiej, Muzeum Literatury im. A. Mickiewicza w Warszawie (dalej: Muz. Lit.), sygn. 2071, t. I, k. 9-10.

3 List do E. Dieckmanna z 4 listopada 1961 r., Muz. Lit., sygn. 2115. 
hiszpańskiego. Mąż jej, opisany przeze mnie w Nocach i dniach, rozpił się i doszedł do takiego stanu, że musiał zostać oddany do zakładu dla narkomanów ${ }^{4}$.

Przypomnijmy, że Dąbrowska (za Abramowskim) uważała wspomnienie za ważny warunek twórczości artystycznej, nazywając je ,jednym ze stanów duchowych, które pozwalają widzieć życie od [...] estetycznej strony”5. Ludziom stamtad, ale czytanym z perspektywy krytyki feministycznej, jest też poświęcony tekst Aleksandry E. Banot. Zapewne sama Dąbrowska żachnęłaby się na autorkę za określenie bohaterów cyklu „odmieńcami”. Pisarka nazwała ich „ludźmi najbardziej odepchniętymi od biesiadnego stołu kultury", Kazimierz Wyka widział zaś w zamyśle twórczym Ludzi stamtad intencję „,szukania człowieka poniechanego”. Banot, odwołując się do publikacji Carol Gilligan, odczytuje zbiór na linii charakterystycznej dla kobiet „etyki troski”, stojącej blisko kategorii współczucia czy litości. Wydaje się jednak, że pisarce chodziło bardziej o godnościowe ujęcie bohaterów tych opowieści oraz o pokazanie, że w najbardziej żałosnej postaci kryje się czujący i myślący człowiek. Tę linię etyczną twórczości Dąbrowskiej zauważyła Eliza Szybowicz, pisząc o bohaterce opowiadania Nasi ludzie w Westfalii:

\section{》 Jeśli już matka Antochny na chwilę przerywa pranie, to nie w przystę- pie patriotyzmu, lecz wimię elementarnego poczucia godności [wyróżn. E. G.]: „Niech ja czuję, że ja jestem człowiekiem, że mam tę jakąś wolność, że mam swobodne życie" ${ }^{6}$ (s. 53).}

Nieporozumieniem wydaje się kategoryczne stwierdzenie Aleksandry Banot, że trudno w przypadku Ludzi stamtąd mówić o literaturze „kobiecej”, ponieważ Dąbrowska bohaterami cyklu czyni także mężczyzn (s. 45). Nie roszcząc pretensji do znajomości koncepcji badań feministycznych i ich narzędzi, pozwalam sobie jednak na uwagę, że statystyka ilościowa nie jest właściwą techniką definiowania literatury.

Do utworów Dąbrowskiej, wobec których istnieje poniekąd historycznoliteracki obowiązek odniesienia się, gdy mamy do czynienia $\mathrm{z}$ tak wieloletnim wysiłkiem twórczym i jednocześnie tak niejednoznacznym efektem literackim, należy druga

4 Osiem listów Marii Dąbrowskiej, podał do druku, przypisy i wstęp: K. Staemmler. wstęp i przypisy tłum. E. Naganowski, „Twórczość” 1979, nr 10, s. 106.

5 M. Dąbrowska, Ludzie stamtąd, wyd. 2, Kraków 1935. Przedr. pt. O „Ludziach stamtąd”, w: eadem, Pisma rozproszone, t. 2, Kraków 1964, s. 608.

6 Cytat z opowiadania Dąbrowskiej pochodzi z tomu: M. Dąbrowska, Wybór pism dla mtodzieży, Warszawa1948, s. 29. 
powieść pisarki. Historycy literatury zbyt łatwo i bezapelacyjnie uznali, że Przygody cztowieka myślacego są utworem $\mathrm{z}$ różnych powodów słabym i nie warto poświęcać mu większej uwagi. Odmiennego zdania jest Marta Wyka, która stawiając tytułowe pytanie Jak czytać dziš „Przygody cztowieka myślacego”, zastanawia się, w jaki sposób we współczesnym odbiorze powieści „wydostać się poza bardzo silne konwencje lektury, na które nakładają się doświadczenia nowoczesności i nowego języka humanistyki”, a także „czy dzieło Dąbrowskiej przekroczyło - mimo wszystko - granice własnej historyczności?” (s. 253). Studium jest propozycją weryfikacji utrwalonego w przekazie historycznoliterackim przekonania o chybionej wizji artystycznej tej powieści. Teza badawcza Marty Wyki poszła w kierunku niekoncentrowania się na edytorskiej realizacji Ewy Korzeniewskiej i poszukiwania w niedokończonym utworze znamion nowoczesności. Jeśli traktować Przygody... jako „arcydzieło niedokończone”, a samą Dąbrowską w czasie pracy nad nimi jako „pisarkę w rozwoju, nie w zastoju" - jak proponuje Marta Wyka - współczesny czytelnik, skupiwszy się na kategorii „człowieka myślącego”, zyska nowe perspektywy lektury. Zwłaszcza jeżeli nie będzie próbował oddzielać biografii autorki, zamkniętej także w dziennikach i listach, od jej dzieła.

Zły stan zdrowia, w jakim znajdowała się pisarka w czasie, który przypadł na ostatnie etapy pracy nad Przygodami..., ilustruje studium Moniki Ładoń „Pismo kliniczne" Marii Dąbrowskiej, słusznie sugerujące, że jedną z przyczyn niemocy twórczej pisarki mogła być pogłębiająca się słabość fizyczna, ale też rujnujący ją psychicznie charakter związku z przyjaciółką, której, w aktach zaborczości, nie potrafiła udzielić zgody na osobność. Ładoń stawia pytanie, na ile zasadne są pretensje i oskarżenia Dąbrowskiej pod adresem Kowalskiej. Wydane w wyborze Dzienniki Anny nie dają pewnej odpowiedzi; można ją znaleźć dopiero w niepublikowanej korespondencji pisarek.

Okupacyjnym opowiadaniom Dąbrowskiej, chybioną decyzją autorki włączonym do Przygód cztowieka myślacego, przez co skazanym niemal na niebyt w odbiorze czytelniczym - a przecież należącym do najlepszych w jej dorobku - poświęcił swoje studium Między Samuelem Pepysem a Josephem Conradem. Heroibumor w opowiadaniach okupacyjnych Marii Dąrowskiej Karol Samsel. Autor ciekawie zdefiniowal to, co stanowi nieustanne wyzwanie w komentowaniu życia i dorobku pisarki, a co jest jedną z myśli przewodnich omawianej książki zbiorowej: wielowymiarowość. Próba lektury opowiadań okupacyjnych przez zwielokrotniony, intertekstualny filtr perspektyw twórców tak odległych jak Samuel Pepys i Joseph Conrad to odczytanie inspirujące i trafnie definiujące specyfikę tych utworów. Uzasadniony jest wywód autora, dotyczący obecności w nich przemieszanych sytuacji komizmu, heroikomizmu i heroizmu, jednak 
wprowadzona tu kategoria bachtinowskiej karnawalizacji wymaga dodatkowego uzasadnienia, zwłaszcza w odniesieniu do W piękny letni poranek, słusznie przez Samsela odczytanego także jako „heroiczny komponent conradowski”, który wydaje się tu głównym kluczem interpretacyjnym. Fascynacja Dąbrowskiej twórczością Conrada sięgała, jak wiadomo, czasów młodości, od wywiadu z nim, przeprowadzonego przez Mariana Dąbrowskiego w I9I4 roku. Pisarka od I924 roku wnikliwie recenzowała powieści autora Murzyna z zatogi „Narcyza”, w 1959 wydała tom Szkiców o Conradzie, zasadnie uznawany za nadal ważny wkład w polskie badania nad pisarzem. Tekstom Dąbrowskiej z tego tomu jest poświęcone studium Jolanty Dudek Marii Dąbrowskiej „Szkice o Conradzie” (1959) czytane dzisiaj. Rozprawa należy więc do grupy tych, które wydobywają mniej znane lub nieco zapomniane osiągnięcia pisarki, ważne dla zrozumienia wielu jej tekstów, a także deklarowanej przez nią postawy życiowej. W 1946 roku, przemawiając jako członkini jury nagrody „Odrodzenia”, życzyła młodym kolegom po piórze, by „niezmordowanie $z$ największą surowością szukali poprzez piękno - jakże często trudnego do wyróżnienia - conradowskiego «błysku prawdy»"7.

W antologii referatów znajdziemy też rozważania nad zagadnieniami i tematami, do których badacze sięgają rzadko lub nie robią tego wcale. I tak - właściwie nikt dotąd nie przyjrzał się bardziej systematycznie translatorskim pracom Dąbrowskiej, a zwłaszcza problemom warsztatowym jej działalności na tym polu. Studium Ewy Kraskowskiej Jak Maria Dabrowska (prze)ttumaczyta Pepysa stanowi chwalebny wyjątek. Wprawdzie autorka deklaruje, że przedstawia jedynie „skromny zarys problematyki”, to jednak jest on obszernym katalogiem pytań z różnych obszarów translatologii, jakie pojawiają się w związku z tym przekładem. Praca przekładowa była, jeśli zaufać deklaracjom Dąbrowskiej, marginesem jej działań twórczych, warto jednak ją przypomnieć, zwłaszcza z powodu ambitnego przedsięwzięcia, jakim stało się właśnie przetłumaczenie (a może spolszczenie?) diariusza Pepysa. Pierwsze, dość słabe próby translatorskie, obejmujące prozę i poezję, pisarka publikowała w czasopismach na początku swej drogi twórczej, w latach I9II-I9I4, dopiero w roku 1926 poważyła się na bardziej ambitne zadanie, jakim był przekład znanej jej z lektury w I9I4 roku niemieckiego wydania powieści duńskiego autora, Jensa Petera Jacobsena Niels Lybne. Pracowała nad nim w trudnym dla niej okresie życia, wypełnionym śmiercią najbliższych. W latach 1925-1927 zmarło kilkoro członków jej rodziny i przyjaciól: najpierw mąż, po śmierci którego myślała o samobójstwie, potem gruźlica zabrała Józefa Dąbrowskiego oraz jego dzieci, następnie zmarł Tadeusz Rzymowski, w końcu także odeszła i matka pisarki. Być może właśnie te okoliczności kazały jej wrócić do lektury Jacobsena. Należałoby jeszcze zastanowić 
się nad wpływem dramatów życiowych pisarki na wybór jej twórczych preferencji. Kraskowska zwraca uwagę na rzetelne przygotowywanie się Dąbrowskiej do pracy przekładowej, zwłaszcza sięganie do dzieł literatury staropolskiej. Warto dodać, że czytała ona też Dzieje angielskie od wstapienia na tron Jakóba II-go Thomasa Babingtona Macaulaya w dziesięciu tomach w polskim przekładzie między innymi Adolfa Pawińskiego i Narcyzy Żmichowskiej z I873 roku, traktując książkę jako podstawę do weryfikacji słownictwa. "Jak się okazuje, przynajmniej na czwórkę odgadywałam tradycje polskie [wyróżn.E. G.] w tej dziedzinie"-oceniała w liście do Kowalskiej ${ }^{8}$. Przede wszystkim jednak sięgnęła do Pamiętnikórw Paska, co dodatkowo świadczy o intencji „spolszczania” czy „sarmatyzacji” lub nawet „plebeizacji” języka i pojęć Pepysa. Zabieg ten, zważywszy na odmienność kontekstów kulturowych obu diarystów, budzi najwięcej uwag i komentarzy, a ponadto - jak słusznie uważa Kraskowska - jest znakomitym materiałem do bardziej zaawansowanych studiów.

Wydaje się, że w sytuacji, gdy wyczerpują się pola badawcze, związane z literackimi osiągnięciami Dąbrowskiej, i gdy jej Dzienniki weszły do kanonu źródeł opisujących epokę, w której dane było jej żyć, coraz większe znaczenie będą miały dokumenty jej życia osobistego, a zwłaszcza listy. Skupienie się Anny Pekaniec na korespondencji pisarki z mężem potwierdza, że pisarstwo tego rodzaju jest traktowane jako ważne źródło inspiracji badawczych. Badaczka słusznie zwraca uwage na doniosłość korespondencji prywatnej „w próbach roz-czytywania twórczości Marii Dąbrowskiej na nowo” (s. 67). Znaczący jest podtytuł referatu: Między życiem a literatura, między mitościq a listami o mitości, pokazujący, że korespondencja pisarza ma zwykle swój drugi, a nawet trzeci plan. Mam na myśli sytuację, gdy twórca już $\mathrm{w}$ chwili pisania listu jako czytelnika widzi nie tylko pierwszego odbiorcę, ale też „późnych wnuków”. W przypadku listów przyszłej pisarki do męża taka sytuacja raczej nie wchodziła w grę; młoda Dąbrowska nie miała jeszcze świadomości, jak potoczy się jej życie i że czeka ją kariera. Ale już późniejsze (w I944 roku) podjęcie decyzji o sporządzeniu odpisów tej korespondencji i poważne zmiany redakcyjne, jakich sama twórczyni w nich dokonała ${ }^{9}$ - upoważniają do stwierdzenia, że listy, w autorskim akcie przysposabiania ich do publikacji, przeznaczonej dla szeroko rozumianego czytelnika, zyskały status materii literackiej. Dotyczy to również korespondencji ze Stanisławem Stempowskim z lat I924-I950, z jednej strony

8 List z 24 października 1947 r., Muz. Lit., sygn. 2153, t. VIII, k. 34-35.

9 Anna Pekaniec błędnie przypuszcza, że podstawą edycji korespondencji Marii Dąbrowskiej z mężem (Ich noce i dnie. Korespondencja Marii i Mariana Dąbrowskich, wstęp i oprac. E. Głębicka, Warszawa 2005) była maszynopisowa wersja przeredagowana przez pisarkę; jest na odwrót - podstawą są rękopisy, natomiast w przypisach odnotowano zmiany redakcyjne wprowadzone przez nią do odpisów. 
przepisywanej i przeredagowanej, z drugiej - na bieżąco wykorzystywanej przy opracowaniu reportaży z podróży. Dąbrowska brała też pod uwagę publikację wyboru korespondencji z Anną Kowalską, także poddanej istotnym zabiegom redakcyjnym. Sugerowała przyjaciólce, że powinny „opracować obiektywną stronę naszych listów, gdyż ich treść na pewno przyda się kiedyś światu”o. W przypadku autorki Nocy $i$ dni traktowanie swojej korespondencji jako rezerwuaru literackiego jest znaczące, gdy weźmiemy pod uwagę autobiografizm jej twórczości. To dla badacza atrakcyjny materiał porównawczy, ale dla pisarki była to sytuacja psychicznie trudna, niosąca ograniczenia, z czego dość wcześnie zdała sobie sprawę i co odczuwała dotkliwie. W Dziennikach odnotowała: „Po napisaniu każdej rzeczy doznaję uczucia, że wypisałam całą siebie, że już nigdy nie będę mogła nic więcej napisać” ${ }^{\text {II. }}$

Przegląd studiów zebranych w książce pokazuje, co dla współczesnych badaczy literatury jest nadal atrakcyjne w twórczości Dąbrowskiej. Do takich ciągle jeszcze otwartych tematów należą Noce i dnie, czytane jednak z innej niż międzywojenna perspektywy. Lena Magnone w studium „W sukurs ginqcemu światu”. „Noce i dnie” Marii Dąbrowskiej i „Przeminęto z wiatrem” Margaret Mitchell podjęła trop komparatystyczny, wcześniej realizowany też w pracach innych badaczy. Oryginalność konceptu autorki polega na tym, że ani Dąbrowska, ani Mitchell nie mogły inspirować się wzajemnie swoimi dziełami. Zbieżność powieści ma więc zasadzać się na analogiach wynikających z intencji pisarek - pokazania świata, który odszedł, oraz nowego, powstającego na gruzach przeszłości. Tytuł tego studium wymaga jednak komentarza. Kazimierz Czachowski w recenzji pod tytułem Epos matżeńskie („Czas” 1932, nr I) świat ziemiaństwa, przedstawiony przez Dąbrowską w pierwszym tomie powieści nazwał nie "ginącym”, a „r z e k o m o [wyróżn. E. G.] ginącym” (co autorka przytacza już prawidłowo w dalszej części rozważań): „Bądź co bądź, w Bogumile Niechcicu - pisał Czachowski - przybywa poważny sukurs rzekomo ginącemu dziś światu”. Magnone dokonała więc w tytule swojej rozprawy zniekształcenia nie tylko cytatu, ale też sensu stwierdzenia krytyka, który zresztą źle odczytał intencje Dąbrowskiej, ta bowiem krytykę świata ziemiańskiego zawarła także w postawie i słowach Bogumiła. Zapewne jest to niezamierzone potknięcie, jednak istotnie rzutuje ono na treść całego wywodu, bardzo zresztą interesującego. Gdyby w tytule przytoczyć cytat prawidłowo, porównanie powieści Dąbrowskiej i Mitchell staje się na jednym z poziomów bezzasadne, bo Przeminęto z wiatrem nie da się czytać jako obrony świata, który „rzekomo ginie”. Nie możemy również

10 List do A. Kowalskiej z 24 lipca 1948 r., Muz. Lit., sygn. 2153, t. X, k. 18.

11 M. Dąbrowska, Dzienniki 1914-1965. Pierwsze pełne wydanie w 13 tomach (bez opracowania edytorskiego) pod kierunkiem T. Drewnowskiego, Warszawa 2009, zapis z 27 czerwca 1924 r. 
mówić o „zdecydowanie konserwatywnym” wydźwięku powieści i „mityzacji sfery ziemiańskiej”, jak odczytuje Noce i dnie Magnone, raczej należałoby pochylić się nad wyraźnie krytycznymi ocenami formacji odchodzącej („Ten świat jest zamknięty ze wszystkich stron. Nie ma na nic żadnego wyjścia. [...] nie wyszedł ze siebie i donikąd nie doszedł") i nowopowstającej oraz pytać, jakie pozytywne wartości promuje pisarka.

Wątkiem także podjętym na nowo jest motyw śmierci w Nocach $i$ dniach w artykule Kariny Jarzyńskiej Psychosomatyzacja śmierci w „Nocach i dniach” Marii Dąbrowskiej.Zmierzenie się Dąbrowskiej z tematem śmierci zapewne miało przyczyny w wydarzeniach jej życia: w dzieciństwie i w okresie poprzedzającym pracę nad powieścią. Niewątpliwie psychika jej matki, ale w konsekwencji także całej rodziny przez wiele lat była naznaczona dramatyczną śmiercią jej starszego braciszka, Janka (Dąbrowska poświęciła mu w IgI4 roku opowiadanie Janek, włączone potem do Nocy $i$ dni). Dąbrowska, żyjąc przez kilka lat jak na cmentarzu, musiała oswoić otaczającą ją śmierć i znaleźć wyższy sens w jej nieuchronności. Może tom Bogumit i Barbara nie powstałby, gdyby nie śmierć Ludomiry Szumskiej w grudniu I927 roku? Czy gdyby żył Marian Dąbrowski, powstałby tom Mitośc? Zmierzenie się z umieraniem w Nocach $i$ dniach pozwoliło pisarce pokazać samotność człowieka w obliczu nieodwołalnego, strach i bezradność, jednocześnie jednak - odwołać się do konstatacji, że tragizm odchodzenia jest łagodzony przez stale odnawiające się życie. Zastosowanie przez Jarzyńską narzędzi z dziedziny psychologii i psychiatrii do analizy wybranych wątków Nocy $i$ dni wydaje się zasadne; już po ukazaniu się pierwszego wydania powieści do pisarki docierały opinie specjalistów traktujących niektóre zawarte tam sytuacje jako niemal kliniczne; dotyczyło to także chwil umierania. Również Piotr Oczko przyjrzał się tej powieści, nie na poziomie interpretacji, lecz opisania, jak wpłynęła ona na życie i status Dąbrowskiej „po Nocach $i$ dniach", przypominając między innymi, że uwięziła ona pisarkę w konwencji literackiej, której nie potrafiła już porzucić, nie była też w stanie stworzyć kolejnego dzieła na miarę tetralogii. W studium „Nie wiem, czy będe jeszcze pisać...” „Noce i dnie” w „Dziennikach” Marii Dąbrowskiej prześledzil ponad trzysta pięćdziesiąt (!) wzmianek autorki z jej dziennika dotyczących powieści, pokazując z jednej strony splot faktów związanych z powstawaniem dzieła, potem jego (wysoką) autooceną i wreszcie sferę, wydawałoby się, prozaiczną, jak bezpieczeństwo finansowe, osiągnięte dzięki dochodom z kolejnych, ogromnych wydań tak przed wojną, jak i po I945 roku. Warto tu przypomnieć, że przedwojenne edycje Nocy $i$ dni na jakiś czas uchroniły jej wydawcę Jakuba Mortkowicza od plajty.

Z Rozczytywania Dąbrowskiej wyłania się świeżą kreską rysowany obraz pisarki, z dzisiejszej perspektywy ocenianej jako osoby niezależnej, dążącej do samorealizacji 
we wszystkich sferach życia, ale też kontrowersyjnej i zaskakującej, targanej najróżniejszymi sprzecznymi uczuciami. Nie poddawała się konwenansom, ale też pilnie chroniła własną prywatność. Swoje wieloletnie związki, najpierw ze Stanisławem Stempowskim, potem Anną Kowalską skrzętnie skrywała nie tylko przed dalszym otoczeniem, ale także przed najbliższą rodziną. W kartach pocztowych, wysyłanych do Stempowskiego - inaczej niż w zamkniętych w kopertach listach - zwracała się do niego per „pan” (dlatego nazywała go Paneczkiem). O tym, jak bliski i zarazem gwałtowny pozostawał związek z Kowalską, można się było przekonać dopiero $\mathrm{w}$ wiele lat po śmierci pisarek, gdy sięgnięto do monumentalnego zbioru ich korespondencji, liczącej około 2300 listów.

Studium Katarzyny Nadany-Sokołowskiej Maria Dąbrowska i George Sand - rozczytywanie podobieństw inspirująco uzupełnia obraz Dąbrowskiej, ocenianej z perspektywy emancypacyjnej, pokazujący, jak bardzo na postawy życiowe obu pisarek wpłynęło przyjęcie ideologii mentorów społecznych: Pierre’a Leroux w przypadku Sand i Edwarda Abramowskiego przez Dąbrowską. Autorka Nocy i dni zżymała się na doszukiwanie się przez krytyków pokrewieństwa swojego pisarstwa z twórczością poprzedniczek, chociażby Elizy Orzeszkowej - jednak Nadanie-Sokołowskiej udało się wskazać tropy, świadczące o istnieniu takich paraleli, na przykład zbieżności poglądów na instytucję małżeństwa z Narcyzą Żmichowską. Zestawienia tego rodzaju pozwalają dostrzec continuum w literaturze, nawet wtedy, gdy sami autorzy zaprzeczają powinowactwom. Studium Nadany-Sokołowskiej pokazuje, jak można „rozczytywać” życie i dzieło Dąbrowskiej z perspektywy feministycznej, odwołującej się do kategorii „tekstu kultury”. $\mathrm{Na}$ emancypacyjność postawy i poglądów pisarki, wprawdzie nie deklarowanych (a nawet zaprzeczanych), zwracają uwagę także inne autorki omawianej księgi. Podkreślając dystans pisarki do tej optyki czytania literatury, przypominają, że „kwestię kobiecą” po prostu realizowała w swoim życiu prywatnym zgodnie ze własnymi przekonaniami, nie odwołując się do żadnej ideologii. Noce i dnie wydają się szczególnie wdzięcznym materiałem do prześledzenia, jak wzorzec emancypacji kobiet polskich, odmienny niż realizowany w twórczości innych literatek, kształtowany jest przez Dąbrowską na przykładzie Agnieszki Niechcicówny, która - jak pisze Monika Świerkosz - „nie postuluje [...] swojej emancypacji, lecz po prostu wciela ją w swoje życie, dostrzegając przy tym wyraźny związek prywatnego i politycznego" (s. 87).

Tak w przypadku zestawienia z życiem i twórczością Sand, jak i innych pisarek, wskazuje się nie tylko na odważne, nieszablonowe wybory życiowe, ale też na wykreowanie przez Dąbrowską „frapujących i niekonwencjonalnych postaci kobiecych" (jak zauważa Nadana-Sokołowska). Wątek ten znajdzie czytelnik także w przywołanym już studium Moniki Świerkosz Kim jest Agnieszka Niechcic. 
Polityka i mitośc w „Nocach i dniach”, kwestionującym słuszność dotychczasowych obiegowych sądów na temat bohaterki i zawierającym próbę odczytania powieści jako emancypacyjnej. O ile postać Barbary, uważanej (również przez Dąbrowską) za najciekawszą bohaterkę tetralogii, została przez krytyków omówiona po wielekroć, Agnieszkę traktowano jako mniej udany twór literacki. Jest w tym sporo racji, niemniej ciekawa wydaje się odpowiedź na pytanie, jakim typem kobiety Dąbrowska c h c i a ł a stworzyć Agnieszkę, o której wiemy, że posiada widoczne rysy pisarki z lat dzieciństwa i młodości. I nawet jeśli ów literacki autoportret jest częściowo wykreowany i wyidealizowany (co też pozostaje ważnym tropem analizy), nie zmienia to faktu, że intencjonalnie mówi wiele o samoocenie Dąbrowskiej i jej poglądach na pozycję kobiety w społeczeństwie.

Drugi dział książki - Oglądanie świata - pokazuje Dąbrowską mniej znaną, między innymi jako reportażystkę i działaczkę spółdzielczą. Otwiera go studium Dokument i Dąbrowska, w którym Joanna Jeziorska-Haładyj, wychodząc od Pism rozproszonych pisarki (Warszawa 1964), skupiła się na jej reportażowej twórczości po I9I4 roku i w latach trzydziestych oraz na zapisanym w Dziennikach powojennym reportażu z fabryki „Parowóz”. Pierwsze szlify dziennikarskie Dąbrowska zdobywała, publikując już w okresie I9Io-I9I2 liczne reportaże i wrażenia z podróży po Belgii, a ponadto korespondencje (Listy z Belgii, podpisywane początkowo pseudonimami lub kryptonimami, a w I9I4 roku także Listy z Londynu). To wtedy, dobrze przed wybuchem pierwszej wojny światowej, ukształtował się jej styl rezonującej dokumentalistki, zajętej sprawami społecznymi, gospodarczymi, rolnymi, literaturą i kulturą życia codziennego. Dodajmy - styl nieskrępowany wymogami gatunku, zależny jedynie od emocjonalnego stosunku piszącej do relacjonowanej kwestii i siły argumentów. Być może dlatego nadal jest on czytelniczo atrakcyjny; przynosi sporą wiedzę o tamtej epoce, a jednocześnie wiele mówi o autorce. Była bowiem Dąbrowska niedocenianą mistrzynią małej formy, w której potrafiła - wychodząc od jednostkowej sytuacji, biografii czy wydarzenia - zamknąć całkiem spory obszar zagadnień, omawianych może i mentorsko, ale postrzeganych gospodarskim okiem osoby, która choć młoda - sporo w świecie pożytecznych rozwiązań problemów społeczeństw zachodnich zdążyła obejrzeć, docenić i precyzyjnie opisać. Rację ma Jeziorska-Haładyj, że młoda Dąbrowska ferowała swoje opinie i postulaty, przepuszczając je przez filtr marzenia o przyszłej wolnej Polsce jako kraju wydobywającego się z zacofania, nędzy, brudu, zabobonu i analfabetyzmu, budowanej na wzór rozwiniętych zachodnich struktur. Autorka tekstu słusznie też uważa, że „poetyka dziennika stanowiła - świadomy lub nie - punkt odniesienia również dla jej [Dąbrowskiej] wczesnych, publikowanych w czasopismach tekstów” (s. 139). Jak wcześniej wspomniano, pisarka wykorzystywała nie tylko dziennik, ale także listy 
prywatne jako zasób literacki, służący następnie tworzeniu tekstów reportażowych. Tak było w przypadku jej listów do Stanisława Stempowskiego z I934 i 1935 roku z podróży morskiej i wyprawy do Jugosławii.

Studium Macieja Dudy Kooperatywy w publicystyce Marii Dabrowskiej to kolejna egzemplifikacja pochylenia się nad ważną dziedziną twórczości pisarki, która słabo przebija się do potocznej wiedzy o niej. Czuła się niepewnie i dyletancko w pracy konspiracyjnej czasu pierwszej wojny. W tej dziedzinie lista jej dokonań jest rzeczywiście skromna i mamy na to osobiste świadectwo młodej działaczki, gdy pisała, że działalność ta przebiegała:

bez wielkiego pożytku dla spraw mnie powierzanych, a ze szkodą być może dla tych, które sama sobie chciałam powierzyć, mianowicie dla twórczości artystycznej, która, niestety, jeszcze wciąż nie jest wciągnięta w rejestr ważnych i świętych powinności ${ }^{\mathrm{I2}}$.

Dlatego też nie zgodziła się zamieścić swoich wspomnień w wydanych w latach I927 i 1929 antologiach Wierna stu̇̇ba i Stużba Ojczyźnie, poprzestając na udziale jako współredaktorki w pierwszej z tych publikacji. Jeżeli nawet nie traktować publicystyki jako twórczości artystycznej, i to w dodatku uważanej za „ważną i świętą powinność" - nie ulega wątpliwości, że przede wszystkim przez publicystykę społeczną młoda Dąbrowska próbowała wpływać na kształt odrodzonej Polski. Jak ważna była dla niej sprawa kooperacji, pokazują dowodnie także Noce i dnie, gdzie problematyka spółdzielczości pojawia się w kilku dyskusjach. Rację ma oczywiście Maciej Duda, pisząc, że wiara Dąbrowskiej, iż kooperacja może być dla społeczeństwa „trzecią drogą”, wytyczoną między kapitalizmem i socjalizmem, z dzisiejszej perspektywy jest naiwna i utopijna. Jednak jądro filozofii spółdzielczości rozumiane mniej dosłownie odkrywa myślenie nakierowane na oddolne działania społeczne, charakterystyczne na przykład dla współczesnych samorządów, których realna siła znacznie osłabia negatywne działania centralistycznej władzy państwowej. Natomiast odczytywana z perspektywy etycznej idea Abramowskiego zdaniem autorki Nocy i dni „przyjmie się dopiero, kiedy ludzie [...] tak pokochają krew płynącą w żyłach bliźniego, jak dziś kochają - rozlaną" - jak napisała w Nocach $i$ dniach. W studium Dudy pojawia się też, dostrzeżony już dobre kilka lat temu i wywołujący spore kontrowersje, problem niechęci do Żydów i wyraźnych akcentów antysemickich w twórczości pisarki. Jest on widoczny także w jej niepublikowanej korespondencji ze Stanisławem Stempowskim, na przykład w liście z i6 października 1933 roku, w którym pisała do towarzysza życia: 


\section{\Jechałam w ścisku żydowskim brudnym i hałaśliwym. Uprzytomniłam sobie w całej pełni, jakim jest podłoże dla antysemityzmu, że leży ono nie tylko w dziedzinie nienawiści rasowej i wstrętu estetycznego, ale i w dziedzinie moralnej. Żyd zachowuje się wszędzie tak, jakby był sam na świecie, i jakby go w ogóle żadne inne stosunki prócz interesów nie mogły łączyć z ludźmi. A gdy je łączą, dyskontuje je, niestety, jak Mort[kowiczowa] na rzecz swych interesów. Oczywiście są wyjątki, o tyle bardziej jaskrawe i odskakujące, o ile ogólny poziom jest rażąco o b cy śród ludzi [wyróżn. M. D.]. Stary Testament! To samo co hitleryzm - dlatego zawrzała tam taka nienawiść, [Niemcy i Żydzi - E. G.] są zbyt podobni do siebie ${ }^{\mathrm{I} 3}$.}

Jest to jedno $z$ owych zapowiadanych we wstępie do recenzowanego tomu pęknięć czy rys w biografii Dąbrowskiej, wymagających spojrzenia sine ira et studio. W kontekście powyższego cytatu słuszna wydaje się uwaga Moniki Bednarczuk w studium „Dziecko ojczyzny”: Maria Dąbrowska, „dziecięctwo” i Wielka Wojna, że „Dą̧browską zajmuje wspólnota kulturowo-etniczna; ją stawia w centrum projektowanego państwa. Ilustracją tego podejścia jest dystans diarystki wobec ludności żydowskiej, nie tyle odrzucanej, ile postrzeganej jako obca, inna, tworząca paralelny do polskiego świat” (s. I62). Także Magnone wspomina o „wyraźnym antysemityzmie" w Nocach i dniach, choć akurat w tej powieści trudno się go doszukać. Postacie Szymszela i Arkuszowej są opisywane wprawdzie jako kulturowo obce, ale z sympatią i współczuciem. Trzeba jednak badaczce oddać sprawiedliwość i przywołać fakt, że niektóre fragmenty powieści dotyczące Żydów różnią się w pierwodrukach w czasopismach i w wydaniu książkowym, gdzie zostały widocznie złagodzone. Natomiast nie ma podstaw, by opisywaną przez Dąbrowską dyskusję o antysemityzmie, prowadzoną w salonie Holszańskich, traktować jako wyraz poglądów autorki powieści (co czyni Magnone). Widziałabym w tej scenie raczej pokazanie przez pisarkę typowych postaw tworzącej się klasy średniej tamtego okresu.

Są i inne rysy na biografii pisarki, dające się odczytać z jej zapisków osobistych, a wskazane przez Bednarczuk, może mniej szokujące, jednak skłaniające do refleksji i krytycznych uwag. Autorka zauważa drażniące samozadowolenie Dąbrowskiej z własnego losu i obojętność wobec jednostkowych tragedii otaczających ją ludzi dotkniętych Wielką Wojną. Tylko czy słusznie Bednarczuk określa tę postawę jako „dziecięctwo”, sugerując niedojrzałość czy nawet infantylizm pisarki? A może tajemnica tkwi w egocentryzmie diarystki i jej ograniczonej empatii w stosunku 
do innych osób? Na myśl przychodzi opowieść Ireny Krzywickiej, że na wieść o śmierci jej synka w 1943 roku Dąbrowska nie zdobyła się na jedno choćby słowo współczucia. Podobnie - czy skłonność Dąbrowskiej do „bezlitosnego obchodzenia się Z wyglądem napotykanych postaci” (s. I72) jest dowodem na jej „dziecięcą spostrzegawczość", czy raczej świadczy o często spotykanym w diariuszu pisarki rysie złośliwości, wynikającej z niechęci do danej osoby? Przypomnijmy jej liczne uwagi na temat wyglądu Zofii Nałkowskiej, na przykład tę z I4 lutego 1947 roku: „Trzyma się coraz lepiej, musi mieć świetnych masażystów i kosmetykarzy, bo nawet gładka się zrobiła na gębie i na szyjsku”. Owszem, Dąbrowska ceniła sobie „dziecięcość” u innych, ale wydaje się, że miała na myśli ciekawość świata i dziecięco radosny zachwyt nad nim. Do uściśleń i sprostowań skłaniają też sądy Elizy Szybowicz, sformułowane w artykule Czyste serca. Dąbrowska dzieciom, czyli nam. Pierwsze publikacje Dąbrowskiej to nie utwory dla dzieci i nie ogłosiła ich - jak pisze Szybowicz - w przededniu pierwszej wojny światowej. Dąbrowska publikowała (i to dużo) już od ıgıo roku. Nadto - niezręcznie brzmi teza, że wielki polski twórca nie może być pisarką dla dzieci. Dokonania Dąbrowskiej w tej dziedzinie rzeczywiście nie imponują, choć - o dziwo - niektóre opowiadania długo utrzymywały się na liście obowiązkowych lektur szkolnych. Współpraca Dąbrowskiej z czasopismem dla młodzieży „Z Bliska i z Daleka”, redagowanym przez Janinę Mortkowiczową i Stefanię Sempołowską zaczęła się faktycznie w I9I4 roku od opublikowania tam części pierwotnej wersji opowiadania Przyjaźn (nr 29-3I), natomiast z pismem „W Słońcu” przyszła autorka Nocy i dni współpracowała dopiero od I9I7 roku.

Studium Macieja Urbanowskiego „Niepojęta skaza” - Gustaw Herling-Grudziński - Marii Dąbrowskiej, oparte na korespondencji pisarki z autorem Dziennika pisanego nocq, mieści się także w nurcie rozważań nad zmiennością jej relacji z innymi osobami. Wspomniane źródła (listy i dziennik Grudzińskiego) znakomicie uzupełniają luki w diariuszu Dąbrowskiej, w którym - być może w obawie przed okiem bezpieki - nie opisywała kontaktów z emigrantami. Nie jest tajemnicą, że stosunek Dąbrowskiej do emigrantów był w niektórych przypadkach naznaczony chłodem i wyniosłością ( $w$ innym miejscu tej książki pisze o tym także Grażyna Borkowska); jej zdaniem prawdę o Polsce i Polakach w kraju mogą znać jedynie ci, którzy po wybuchu wojny w nim pozostali, a po 1945 roku przeszli lekcję komunizmu. Rodakom za granicą odmawiała Dąbrowska prawa do oceniania postaw i decyzji obywateli w PRL-u, uważała też, że polityczne myślenie, opinie i propaganda kręgów wychodźstwa szły w kierunku dzielenia Polaków na wolnych na emigracji i zniewolonych w kraju. Urbanowski, śledząc zapisy diariuszy i korespondencję obojga pisarzy, pokazał, jak zmieniały się oceny Herlinga w miarę upływu lat - szacunek i podziw ustępował miejsca zdziwieniu, konsternacji i kry- 
tycyzmowi, gdy - znając uwikłania autorki $N a$ wsi wesele w relacje z władzami - był świadkiem jej przykrych demonstracji wobec emigrantów, także rosyjskich. „Skaza” Dąbrowskiej - to temat, który można by i chyba należałoby podjąć również w odniesieniu do relacji z innymi twórcami, ale i z osobami znanymi jej z kręgu na przykład polityki. Wątek „skaz” i „pęknięć” na portrecie pisarki jest także wyrazisty w zamykającym książkę studium Grażyny Borkowskiej Marii Dąbrowskiej kompozycja istnienia i abdykacja z życia. Zasadne wydaje się chociażby pytanie autorki, postawione w związku ze stosunkiem Dąbrowskiej do władz PRL-u, „skąd tyle niechęci do rodaków, kolegów, którzy postępowali w podobny [jak ona - E. G.] sposób?” (s. 316). Borkowska słusznie uważa, że życie Dąbrowskiej jako twórcy przełamało się po sukcesie Nocy i dni. Ogromna popularność powieści i entuzjastyczne z reguły przyjęcie przez krytykę postawiły ją na najwyższym podium. Kryło się w tej nobilitacji zobowiązanie, któremu pisarka nie podołała, co wywołało w niej trwałą frustrację. Prawda, nie poradziła sobie z Przygodami cztowieka myślacego, powieścią, do pisania której zasiadła, nie mając na nią pomysłu. Nie powinna publikować w prasie fragmentów, nie dysponując koncepcją całości. Skupieniu się na pracy przeszkadzała też niemożność uporządkowania spraw osobistych. Ale czy cała powojenna twórczość Dąbrowskiej jest chybiona? Przecież nie, choć pisarka tylko w opowiadaniach okupacyjnych wzniosła się do wyżyn Ludzi stamtad.

$\mathrm{Na}$ koniec kilka drobnych uwag natury redakcyjnej. Wszystkie przytoczenia Dzienników Dąbrowskiej pochodzą z ich pełnego wydania w trzynastu tomach, w których rozmyślnie nie przeprowadzono żadnych modernizacji i nie poprawiano błędów autorki. Myślę jednak, że w przedrukach cytaty należałoby poddać obróbce redakcyjnej, uwspółcześniając tak pisownię (na przykład w słowach: aljenowany, zlekka), jak i interpunkcję. Zasada modernizacji nie podlega wszak dyskusji, natomiast błędy autora trzeba milczkiem korygować. Przy cytatach z Dzienników raczej podawałabym datę przywołanego zapisu (co ma kluczowe znaczenie w jego zrozumieniu) zamiast szczegółowej lokalizacji w tomie. Zakradła się też literówka w nazwisku (na s. 276) - w miejsce: „Środka” powinno być: „Śródka”.

Tom Rozczytywanie Dąbrowskiej jest ważną książką zbiorową, trzecią po Pięćdziesiąt lat twórczości Marii Dąbrowskiej (red. E. Korzeniewska i inni, Warszawa I963) i Księdze kaliskiej (red. T. Drewnowski i inni, Kalisz 1996), poświęconych w całości autorce Nocy $i$ dni. Dowodnie pokazuje, że nowe, niekonwencjonalne spojrzenia badawcze pozwalają zobaczyć dzieło i życie autorki Nocy $i$ dni w innej odsłonie. Niektóre stwierdzenia, zawarte w artykułach prowokują polemikę czy chęć uzupełnień, ale i w tym zawiera się dodatkowa wartość zbioru. Dąbrowska czytana dzisiaj jest inną pisarką niż ta, którą odnajdujemy w sporach i polemikach międzywojnia i powojnia, ale też inną, niż prezentowana w aktach autokreacji tak 
w utworach (zwłaszcza w tetralogii) jak wywiadach, czy nawet zapiskach dziennikowych. Autorom Rozczytywania Dąbrowskiej udało się odnaleźć wiele nowych, pomijanych wcześniej lub tajonych wątków życia i twórczości pisarki; próba ich rozczytania okazała się tak w zamyśle, jak i w realizacji satysfakcjonująca i atrakcyjna. 